\title{
Quantitative and qualitative damage caused by Oebalus poecilus (Hemiptera, Pentatomidae) to upland rice cultivated in new agricultural frontier of the Amazon rainforest (Brazil)
}

\author{
Danos quantitativos e qualitativos causados por Oebalus poecilus (Hemiptera, \\ Pentatomidae) em arroz de terras altas cultivado na nova fronteira agrícola \\ da Floresta Amazônica (Brasil)
}

\author{
Diones Krinski ${ }^{*}$, Luís Amilton Foerster ${ }^{2}$
}

\author{
'Universidade do Estado de Mato Grosso/UNEMAT, Departamento de Ciências Biológicas, Tangará da Serra, MT, Brasil \\ 2Universidade Federal do Paraná/UFPR, Departamento de Zoologia, Curitiba, PR, Brasil \\ ${ }^{*}$ Corresponding author: dioneskrinski@gmail.com \\ Received in September 15, 2016 and approved in April 3, 2017
}

\begin{abstract}
Oebalus poecilus (Dallas 1851) is one of the stink bug species of great economic importance for rice producers in Brazil of irrigated, flood and upland cropping systems. These pentatomids are known as stink bugs of panicles, because both nymphs and adults feed mainly on panicles. Stink bug attacks result in pecky (spots) seeds, lower mass, germinative reduction and deformed grains. Bearing these factors in mind, the aim of this study was to evaluate the quantitative and qualitative losses in commercial cultivars of upland rice (Cambará variety), submitted to different population levels of stink bugs of panicles, O. poecilus, at different reproductive growth stages. The results show that in upland rice (Cambará variety), the rice grains are susceptible to quantitative (number and weight) and qualitative (pecky, atrophy, chalky and broken grains) damage during all panicle development. However, when the insects feed during anthesis/caryopsis and milky stage cause significantly greater percentage of empty grains (up to 83\%) than when they feed of grains during later phases of panicle development. This characteristic was also observed for the reduction in grain weight. This information may benefit producers and other researchers, allowing them to focus on the monitoring efforts of $O$. poecilus in most susceptible phases of the attack of this insect. This will enable decision-making about what control measures should be taken, and when, in order to control stink bugs of panicles.
\end{abstract}

Index terms: Oryza sativa; stink bug of panicles; damage level; integrated pest management.

\begin{abstract}
RESUMO
Oebalus poecilus (Dallas 1851) é uma das espécies de percevejos de grande importância econômica para os produtores de arroz no Brasil em sistemas de cultivo irrigados, de inundação ou de terras altas. Estes pentatomídeos são conhecidos como percevejos das panículas, porque ninfas e adultos alimentam-se principalmente dessas estruturas. O ataque deste percevejo resulta em grãos manchados, massa inferior, redução germinativa e grãos deformados. Considerando isso, o objetivo deste estudo foi avaliar as perdas quantitativas e qualitativas na cultivar comercial de arroz de terras altas (variedade Cambará), submetidas a diferentes níveis de infestação de percevejos de panículas, O. poecilus, em diferentes estágios de crescimento reprodutivo das plantas de arroz. Os resultados mostram que em arroz de terras altas (variedade Cambará), os grãos de arroz são suscetíveis a danos quantitativos (número e peso) e qualitativos (grãos manchados, atrofiados, gessados e quebrados), durante todo o desenvolvimento da panícula. No entanto, quando os insetos se alimentam durante os estágios de antese/cariopse e leitosa causam percentual significativamente maior de grãos vazios (até 83\%) do que quando se alimentam de grãos durante as fases posteriores do desenvolvimento da panícula. Esta característica foi também observada para a redução de peso dos grãos. Esta informação pode beneficiar os produtores e outros pesquisadores, permitindo que concentrem os esforços de monitoramento de O. poecilus em fases mais suscetíveis ao ataque deste inseto. Também serve de base para a tomada de decisão sobre quando e quais medidas de controle devem ser realizadas, a fim de controlar os percevejos das panículas.
\end{abstract}

Termos para indexação: Oryza sativa; percevejo das panículas; nível de dano; manejo integrado de pragas.

\section{INTRODUCTION}

Among the major late-season pests of rice, the stink bugs of the Oebalus genus (Hemiptera, Pentatomidae), especially Oebalus poecilus (Dallas 1851), are insects of great economic importance to producers of rice in Brazil in all cropping systems (irrigation, flood or upland) (Vieira;
Santos; Sant'Ana, 1999; Silva; Ferreira; Vieira, 2002). These pentatomids are known as stink bugs of panicles, because nymphs and adults feed mainly on this part of the plant. During the direct feeding in these structures, these insects cause quantitative and qualitative reductions in grain production (Vieira; Santos; Sant' Ana, 1999; Ferreira; Vieira; Rangel, 2002; Fritz et al. 2008). 
The most severe attacks result in the formation of seeds with peck in the endosperm, lower mass, reduction in germination and grains with a "plastered" appearance and irregular size, which are often broken during the processing (Chaves; Ferreira; Garcia, 2001; Silva; Ferreira; Vieira, 2002; Ferreira; Vieira; Rangel, 2002).

Furthermore, the intensity of peck on rice grains may increase according to the feeding activity of $O$. poecilus, which are also vectors of various fungi (Kennard, 1966; Antoniolli; Porto, 1995).

Although there are many studies reporting the damage of several species of Oebalus, most were conducted in irrigated rice (Ferreira; Vieira; Rangel, 2002; Ferreira; Barrigossi, 2006). Moreover, these studies usually consider only the number of spikelets produced (filled and empty) and the weight of the grains after infestation with insects, and do not consider qualitative damage such as damaged kernels (pecky, atrophied and chalky) and broken grains (grits). Thus, are incipient the info of damage that this stink bug can cause in upland rice, mainly in new agricultural areas, for example in crops grown in Pará State, in the Amazon rainforest region.

According to Albuquerque (1993), the life cycle of $O$. poecilus is synchronized with its host plants, and its success as a rice pest is strictly linked to the phenological stage of the plants, since cultivation occurs precisely during the active phase of this pentatomid (Greve; Fortes; Grazia, 2003). As the intensity of attack from stink bugs is related to panicle development, the losses originating from such attacks in different reproductive growth stages of rice inflorescence are probably variable.

Therefore, the objective of this study was to evaluate the quantitative and qualitative losses in commercial cultivars of upland rice (Cambará variety) submitted to different population levels of stink bugs of panicles, O. poecilus, and reproductive growth stages.

\section{MATERIAL AND METHODS}

\section{Study area, sampling time and experimental data}

The study was carried out during the 2011/2012 harvest in an upland rice field (Cambará variety) at the Florentino Farm $\left(7^{\circ} 07^{\prime} 45.71^{\prime \prime} \mathrm{S} 55^{\circ} 23^{\prime} 21.13^{\prime \prime} \mathrm{W}\right)$ in the municipality of Novo Progresso, Pará State, Brazil. The experiments were conducted in three phenological stages of panicles according to the timeline proposed by Counce, Keisling and Mitchell (2000): R4/R5 (anthesis: caryopsis stage), R6 (grain filling: milk stage) and R7 (stiffening of grains, waxy and stiff mass: soft dough stage). For each growth stage three treatments were performed, with one, two and four adults of $O$. poecilus for each inflorescence of rice, besides the control treatment (no stink bugs: uninfested) (Figure 1). The stink bugs used in the experiments were collected from natural populations found in the plantation itself. The
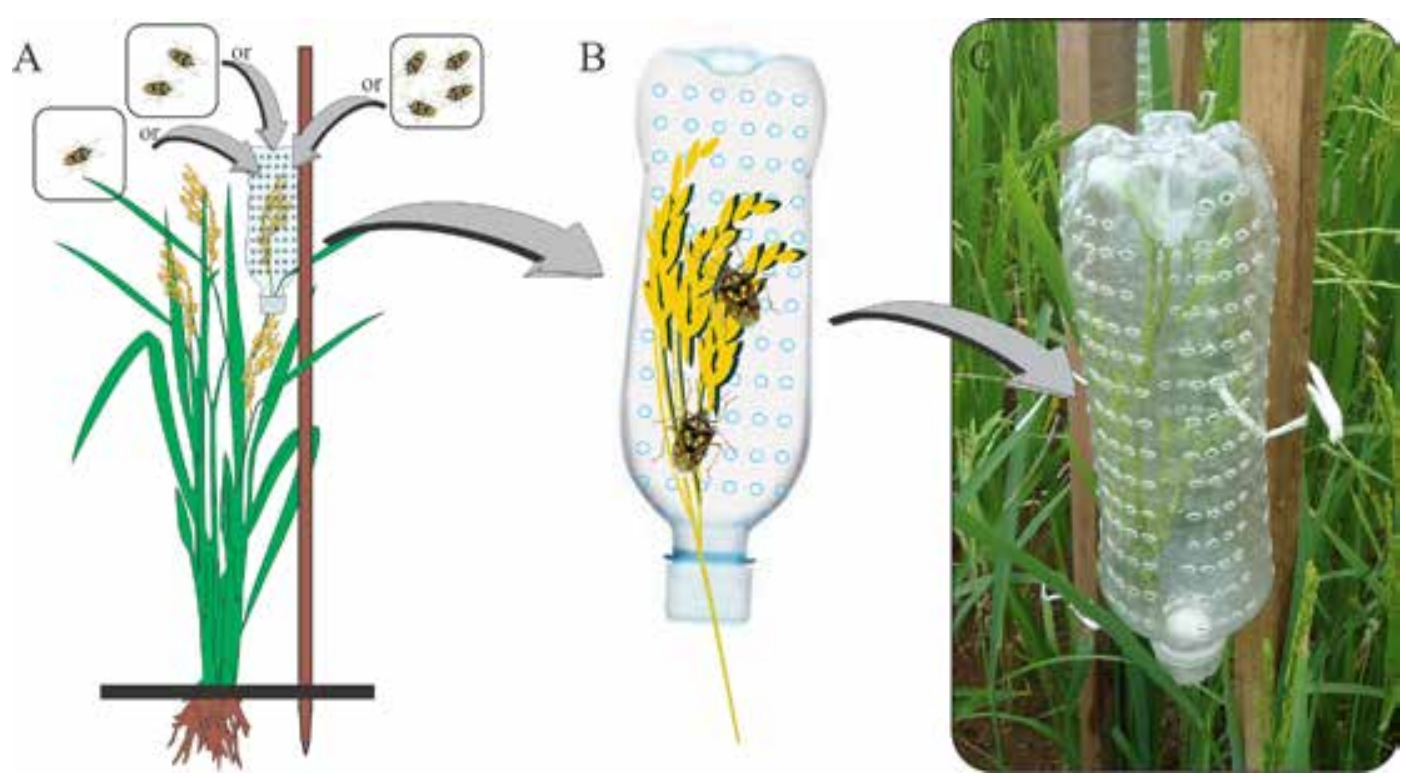

Figure 1: Experiment for isolation of Oebalus poecilus in each treatment: A) schematic structure mounted on each rice plant; B) detail of stink bugs and panicle inside the "cage"; and C) structure placed in field. 
insects were maintained in containers (with only water as a food source) for 24 hours prior to the infestation in the treatments and only insects that were physically and morphologically healthy were considered for the experiments.

The experiment lasted seven days. After this period, the cages were removed, and to ensure that the plants were not attacked by other insects, a chemical control with permethrin (Pounce ${ }^{\circledR} 384$ EC) was used weekly until harvest. The cages were monitored daily to replace dead stink bugs. The panicles were harvested after complete maturation of the grains and then brought to the laboratory, where manual threshing and packaging of spikelets in properly identified paper envelopes took place. After drying, the spikelets were weighed, and classified as "empty" or "filled (grains)," and then spikelets were peeled using a Zaccaria Rice Tester, model PAZ-1 DTA.

\section{Data analysis and statistics}

In each treatment, the quantity of filled grain and empty spikelets, and the number of whole, broken (rice grits) and damaged kernels (pecky, atrophied and chalky) were evaluated (Figure 2). The chalky grain is characterized by a totally opaque color, similar to plaster (Ishymaru et al., 2009). The atrophied grain occurs when the grain does not develop normally due to feeding of stink bugs in spikelets usually in grains with milky endosperm (Ferreira; Barrigossi, 2006). We also analysed the total weight of grains per panicle, the weight of whole grains, pecky rice (spotted), broken grains, the Damage Percentages in Amount of Grains per panicle (DPAG) and the Damage Percentages in the Grain Weight per panicle (DPGW) calculated by the following equations: DPAG $=[(\mathrm{NPRG}+\mathrm{NAG}+\mathrm{NCG})] / \mathrm{TG}) * 100$, where $\mathrm{NPRG}=$ Number of Pecky Rice Grains, NAG $=$ Number of Atrophied Grains, NCG $=$ Number of Chalky Grains and $\mathrm{TG}=$ Total number of Grains per panicle, and $\mathrm{DPGW}=[(\mathrm{WPG}+\mathrm{WAG}+\mathrm{WCG}+\mathrm{WBG})] / \mathrm{TW}) * 100$, where $\mathrm{WPG}=$ Weight of Pecky Grains, $\mathrm{WAG}=$ Weight of Atrophied Grains, WCG = Weight of Chalky Grains, $\mathrm{WBG}=$ Weight of Broken Grains (grits) and TW = Total Weight of grains per panicle.

Data were submitted to normality and homoscedasticity tests. The treatment effect was studied by generalized linear model (GLM) and by deviance analysis, considering a statistical model that includes varying in accordance with the stink bug numbers used for infestation (x1) and reproductive growth stages of rice plants $(x 2)$, and the interaction $\times 1: x 2$. The data were adjusted to a Poisson distribution with a $\log$ link function, and when they were significant a contrast multiple comparison (Package contrast) or KruskalWallis (Package agricolae) test was carried out in R Core Team version 3.1.1 software (2014).
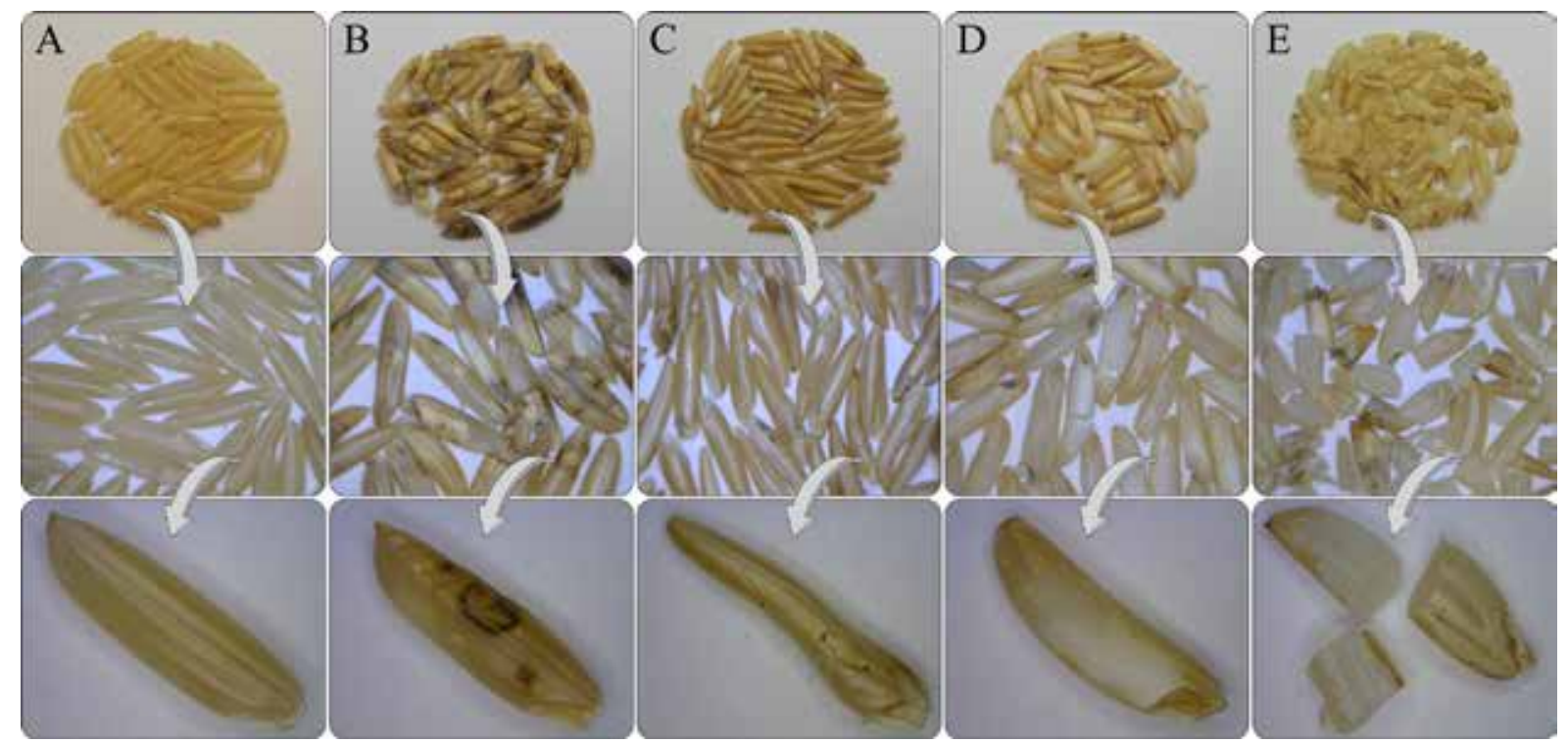

Figure 2: Types of grains. A) whole grains; B) pecky grains; C) atrophied grains; D) chalky grains; and E) broken grains (grits). 


\section{RESULTS AND DISCUSSION}

No significant difference in the total number of spikelets in different infestation levels $\left(\chi^{2}=19.47\right.$; $\mathrm{df} .=3.356 ; \mathrm{p}=0.477)$ and the reproductive growth stages $\left(\chi^{2}=21.587 ; \mathrm{df} .=2.354 ; \mathrm{p}=0.252\right)$ was verified. However, significant differences were observed in empty and filled spikelet numbers in relation to the stink bug infestations (empty spikelets: $\chi^{2}=4562.2$; df. $=3.356 ; \mathrm{p}>0,001$; filled spikelets: $\chi^{2}=1103.3$; $\mathrm{df} .=3.356 ; \mathrm{p}<0.001)$ and reproductive growth stages (empty spikelets: $\chi^{2}=5035.8 ; \mathrm{df} .=2.354 ; \mathrm{p}<0.001$; filled spikelets: $\chi^{2}=1431.3$; df. $\left.=2.354 ; \mathrm{p}<0.001\right)$. The mean number of filled and empty spikelets varied from $29.9 \pm 3.1$ to $153.7 \pm 6.0$ and $11.2 \pm 0.7$ and $146.4 \pm$ 5.4 , respectively (Figure 3 ).

Note that in all reproductive growth stages tested there was an increase in the number of empty spikelets and consequently a reduction in filled spikelets in relation to the stink bug numbers, most notably in the caryopsis stage (R4/R5), which was the stage most susceptible/sensitive to O. poecilus attack (Figure 3).

The number of whole grains (mean) ranged from $16.8 \pm 2.7$ to $111.2 \pm 5.4$ and was most affected when the infestation occurred with four stink bugs in the caryopsis stage. However, the presence of at least one $O$. poecilus in all tested growth stages was sufficient to reduce significantly the number of whole grains. The mean number of pecky rice grains per panicle varied from 8.3 \pm 1.3 to $19.6 \pm 1.8$ and was higher in the milk and soft dough stages. The number of atrophied grains per panicle (mean) ranged from $3.4 \pm 0.4$ to $8.9 \pm 1.0$ and was highest in the milk stage, and the mean number of chalky grains ranged from $1.0 \pm 0.3$ to $7.4 \pm 1.0$ and was higher in the soft dough stage (Table 1).

The percentage of pecky, chalky, atrophied and whole grains showed significant results between the reproductive growth stages and the number of stink bugs used. In control treatment the percentage of whole grains was greater than $80 \%$, and among the stages analysed presented lower values in caryopsis, milk and soft dough stages, in that order, for infestations with four, two and one stink bug, respectively (Table 1).

The total weight of grains per panicle varied from 0.56 to $3.18 \mathrm{~g}$ between treatments, and was lowest in treatments performed in the caryopsis stage, after infestation with four stink bugs. The mean weight of the whole grains varied from 0.40 to $2.70 \mathrm{~g}$ between treatments. The lowest weights for all grains at each developmental stage were $0.56 \mathrm{~g}$ (caryopsis stage), $2.09 \mathrm{~g}$ (milk stage) and $2.47 \mathrm{~g}$ (soft dough stage) for infestations with four stink bugs. This same pattern was observed for the weights of whole grains (Table 2).

The mean weight of damaged grains (pecky, atrophied and chalky) ranged from 0.10 to $0.44 \mathrm{~g}$. And the weight of broken grains (grits) ranged from 0.07 to $0.51 \mathrm{~g}$ between treatments, with the highest values observed in the soft dough stage (Table 2).

The largest reductions in the total grain weight and weight of whole grains occurred in infestation with one stink bug in the caryopsis stage and smaller reductions were observed in the milk and soft dough stages, in that order (Table 2).
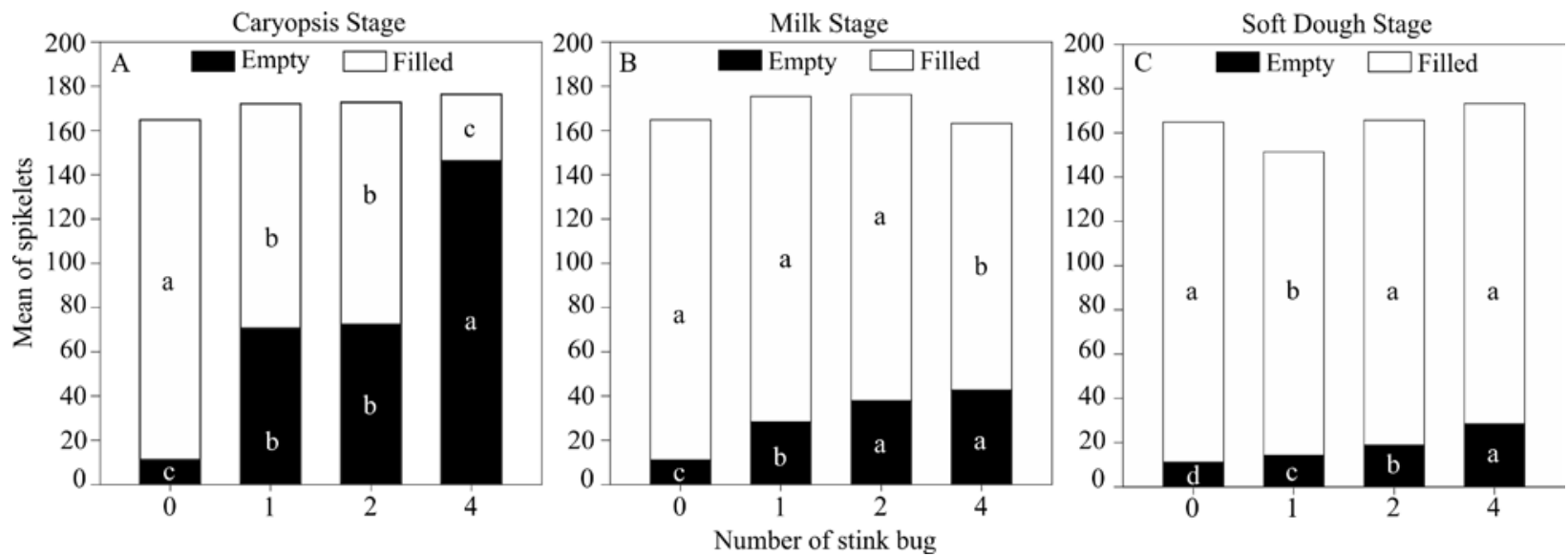

Figure 3: Average of filled (white bar) and empty (black bar) spikelets relative to the number of Oebalus poecilus and reproductive growth stages of upland rice. 
Table 1: Mean of whole, pecky, atrophied and chalky grains by rice panicle after infestation with different Oebalus poecilus numbers and growth stages.

\begin{tabular}{cccccc}
\hline $\begin{array}{c}\text { Reproductive } \\
\text { growth stages }\end{array}$ & $\begin{array}{c}\text { Number of } \\
\text { insects }\end{array}$ & Whole grains $^{1}$ & Pecky grains $^{1}$ & Atrophied grains $^{1}$ & Chalky grains $^{1}$ \\
\hline R4/R5 (Caryopsis) & 0 & $111.23 \pm 29.89 \mathrm{a}$ & $14.33 \pm 10.01 \mathrm{a}$ & $4.70 \pm 3.90 \mathrm{ab}$ & $5.43 \pm 3.50 \mathrm{a}$ \\
& 1 & $56.73 \pm 26.28 \mathrm{~b}$ & $14.07 \pm 7.72 \mathrm{a}$ & $4.83 \pm 2.45 \mathrm{a}$ & $2.00 \pm 5.80 \mathrm{~b}$ \\
& 2 & $54.97 \pm 25.27 \mathrm{~b}$ & $13.07 \pm 6.77 \mathrm{a}$ & $5.97 \pm 3.99 \mathrm{a}$ & $2.93 \pm 5.88 \mathrm{~b}$ \\
& 4 & $16.80 \pm 15.15 \mathrm{c}$ & $8.33 \pm 7.18 \mathrm{~b}$ & $3.40 \pm 3.59 \mathrm{~b}$ & $0.96 \pm 1.90 \mathrm{~b}$ \\
\cline { 2 - 6 } & $\mathrm{X}^{2}$ & 80.55 & 13.10 & 10.01 & 37.78 \\
& $\mathrm{P}$ & $<0.001$ & 0.004 & 0.018 & $<0.001$ \\
\hline R6 (Milky) & 0 & $111.23 \pm 29.89 \mathrm{a}$ & $14.33 \pm 10.01 \mathrm{a}$ & $4.70 \pm 3.90 \mathrm{c}$ & $5.43 \pm 3.50 \mathrm{a}$ \\
& 1 & $84.83 \pm 30.87 \mathrm{~b}$ & $15.73 \pm 7.18 \mathrm{ab}$ & $5.57 \pm 3.62 \mathrm{bc}$ & $5.06 \pm 4.87 \mathrm{a}$ \\
& 2 & $73.33 \pm 25.29 \mathrm{bc}$ & $19.63 \pm 9.83 \mathrm{~b}$ & $8.90 \pm 5.68 \mathrm{a}$ & $2.23 \pm 2.31 \mathrm{~b}$ \\
& 4 & $66.73 \pm 21.67 \mathrm{c}$ & $12.70 \pm 6.29 \mathrm{~b}$ & $7.56 \pm 4.72 \mathrm{ab}$ & $2.13 \pm 2.77 \mathrm{~b}$ \\
\hline & $\mathrm{X}^{2}$ & 32.88 & 10.75 & 14.51 & 22.73 \\
& $\mathrm{P}$ & $<0.001$ & 0.013 & 0.002 & $<0.001$ \\
\hline R7 (Soft Dough) & 0 & $111.23 \pm 29.89 \mathrm{a}$ & $14.33 \pm 10.01$ & $4.70 \pm 3.90$ & $5.43 \pm 3.50 \mathrm{ab}$ \\
& 1 & $81.00 \pm 26.96 \mathrm{~b}$ & $13.53 \pm 9.76$ & $5.37 \pm 3.09$ & $7.37 \pm 5.44 \mathrm{a}$ \\
& 2 & $83.30 \pm 26.33 \mathrm{~b}$ & $15.93 \pm 7.17$ & $4.20 \pm 2.69$ & $4.93 \pm 3.35 \mathrm{ab}$ \\
& 4 & $81.83 \pm 27.77 \mathrm{~b}$ & $15.30 \pm 8.10$ & $3.37 \pm 2.26$ & $3.93 \pm 3,99 \mathrm{~b}$ \\
\hline & $X^{2}$ & 19.70 & 4.42 & 7.30 & 9.09 \\
& $\mathrm{P}$ & $<0.001$ & 0.219 & 0.062 & 0.028 \\
\hline
\end{tabular}

${ }^{1}$ Mean \pm SD. Equal letters indicate no difference between treatments for each growth stage by Kruskal-Wallis test $(P=0.05)$.

Damage proportion of number and weight grains varied in relation to the number of $O$. poecilus (number of grains, $\chi^{2}=3.920 ; \mathrm{df} .=3.356 ; \mathrm{p}<0.001$; weight of grains, $\left.\chi^{2}=8.702 ; \mathrm{df} .=3.356 ; \mathrm{p}<0.001\right)$ and of reproductive growth stages (number of grains, $\chi^{2}=2.074 ;$ df. $=2.354 ; \mathrm{p}<0.001$; weight of grains, $\chi^{2}=$ 0.427 ; df. $=2.354 ; \mathrm{p}=0.015$ ), with an increase in the damaged proportion in line with the increased number of stink bugs being observed, irrespective of reproductive growth stages (Figure 4).

Damage related to the quantity of grain produced after infestation in different growth stages reached $49.8 \%$ in the caryopsis stage with infestations of four $O$. poecilus. Damage associated with a reduction in the weight (mass) of grain produced reached $39.7 \%$ for the milk stage with infestations of two stink bugs. However, the weight of grains showed a significant reduction after infestation with only one stink bug in the caryopsis stage, and showed an even greater weight reduction in the milk and soft dough stages (Figure 4).
Several species of the Oebalus genus have been studied with regard to damage caused to rice grains in many countries that produce this cereal. The main species are Oebalus pugnax (Fabricius, 1775), Oebalus insularis Stål, 1872 and Oebalus ypsilongriseus (De Geer, 1773), found in the United States (Jones; Cherry, 1986; Cherry; Jones; Deren, 1998; McPherson; McPherson, 2000; Way, 2003; Cherry; Nuessly, 2010; Awuni et al., 2015), $O$. insularis in Venezuela, Mexico, Cuba and the Caribbean (Sailor, 1944; Carbonell; Sousa, 1980; Gutiérrez et al., 1987; Pantoja et al., 1999; Guharay, 1999; Vivas; Notz, 2009; 2010; 2011; Rodríguez et al., 2006), Oebalus ornatus Sailer, 1944 in Colombia (Pantoja; Garcia; Duque, 2000) and $O$. poecilus and $O$. ypsilongriseus in Brazil, Guyana and Suriname (Rai, 1971; 1974; Halteren, 1972; Ferreira; Vieira; Rangel, 2002). The types of damage caused by these species (quantitative and/or qualitative) are known principally for growing rice or flood (Ferreira; Vieira; Rangel, 2002; Ferreira; Barrigossi, 2006). 
Table 2: Total weight of grains, weight of whole grains, damaged (pecky, atrophied and chalky) and broken (grits) per panicle after infestation with different Oebalus poecilus numbers and growth stages.

\begin{tabular}{cccccc}
\hline $\begin{array}{c}\text { Reproductive } \\
\text { growth stages }\end{array}$ & Number of insects & Total weight ${ }^{1}$ (g.) & Whole grains ${ }^{1}$ (g.) & $\begin{array}{c}\text { Damaged grains } \\
\text { (g.) }\end{array}$ & Broken grains $^{1}$ (g.) \\
\hline & 0 & $3.18 \pm 1.20 \mathrm{a}$ & $2.70 \pm 1.17 \mathrm{a}$ & $0.21 \pm 0.15 \mathrm{a}$ & $0.26 \pm 0.13 \mathrm{a}$ \\
R4/R5 & 1 & $1.71 \pm 0.62 \mathrm{~b}$ & $1.25 \pm 0.55 \mathrm{~b}$ & $0.18 \pm 0.09 \mathrm{a}$ & $0.29 \pm 0.14 \mathrm{a}$ \\
(Caryopsis) & 2 & $1.73 \pm 0.54 \mathrm{~b}$ & $1.28 \pm 0.54 \mathrm{~b}$ & $0.17 \pm 0.09 \mathrm{a}$ & $0.28 \pm 0.12 \mathrm{a}$ \\
& 4 & $0.56 \pm 0.46 \mathrm{c}$ & $0.40 \pm 0.33 \mathrm{c}$ & $0.10 \pm 0.08 \mathrm{~b}$ & $0.07 \pm 0.08 \mathrm{~b}$ \\
\cline { 2 - 6 } & $\chi^{2}$ & 83.41 & 82.58 & 19.03 & 49.53 \\
& $\mathrm{P}$ & $>0.001$ & $>0.001$ & $>0.001$ & $>0.001$ \\
\hline R6 & 0 & $3.18 \pm 1.20 \mathrm{a}$ & $2.70 \pm 1.17 \mathrm{a}$ & $0.21 \pm 0.15 \mathrm{c}$ & $0.26 \pm 0.13 \mathrm{c}$ \\
(Milky) & 1 & $2.60 \pm 0.88 \mathrm{~b}$ & $1.90 \pm 0.87 \mathrm{~b}$ & $0.22 \pm 0.10 \mathrm{c}$ & $0.48 \pm 0.13 \mathrm{a}$ \\
& 2 & $2.38 \pm 0.58 \mathrm{bc}$ & $1.46 \pm 0.50 \mathrm{c}$ & $0.44 \pm 0.15 \mathrm{a}$ & $0.48 \pm 0.24 \mathrm{ab}$ \\
& 4 & $2.09 \pm 0.60 \mathrm{c}$ & $1.35 \pm 0.48 \mathrm{c}$ & $0.33 \pm 0.10 \mathrm{~b}$ & $0.41 \pm 0.18 \mathrm{~b}$ \\
\hline & $\chi^{2}$ & 24.24 & 41.31 & 47.44 & 32.03 \\
& $\mathrm{P}$ & $<0.001$ & $<0.001$ & $<0.001$ & $<0.001$ \\
\hline R7 & 0 & $3.18 \pm 1.20 \mathrm{a}$ & $2.70 \pm 1.17 \mathrm{a}$ & $0.21 \pm 0.15 \mathrm{c}$ & $0.26 \pm 0.13 \mathrm{~b}$ \\
& 1 & $2.50 \pm 0.67 \mathrm{~b}$ & $1.66 \pm 0.55 \mathrm{~b}$ & $0.39 \pm 0.16 \mathrm{ab}$ & $0.45 \pm 0.18 \mathrm{a}$ \\
(Soft Dough) & 2 & $2.56 \pm 0.54 \mathrm{~b}$ & $1.67 \pm 0.48 \mathrm{~b}$ & $0.40 \pm 0.11 \mathrm{a}$ & $0.49 \pm 0.14 \mathrm{a}$ \\
& 4 & $2.47 \pm 0.75 \mathrm{~b}$ & $1.62 \pm 0.63 \mathrm{~b}$ & $0.33 \pm 0.15 \mathrm{~b}$ & $0.51 \pm 0.19 \mathrm{a}$ \\
\hline & $\chi^{2}$ & 10.51 & 31.98 & 34.38 & 38.86 \\
& $\mathrm{P}$ & 0.014 & $<0.001$ & $<0.001$ & $<0.001$ \\
\hline
\end{tabular}

${ }^{1}$ Mean \pm SD. Equal letters indicate no difference between treatments for each growth stage by Kruskal-Wallis test $(P=0.05)$.
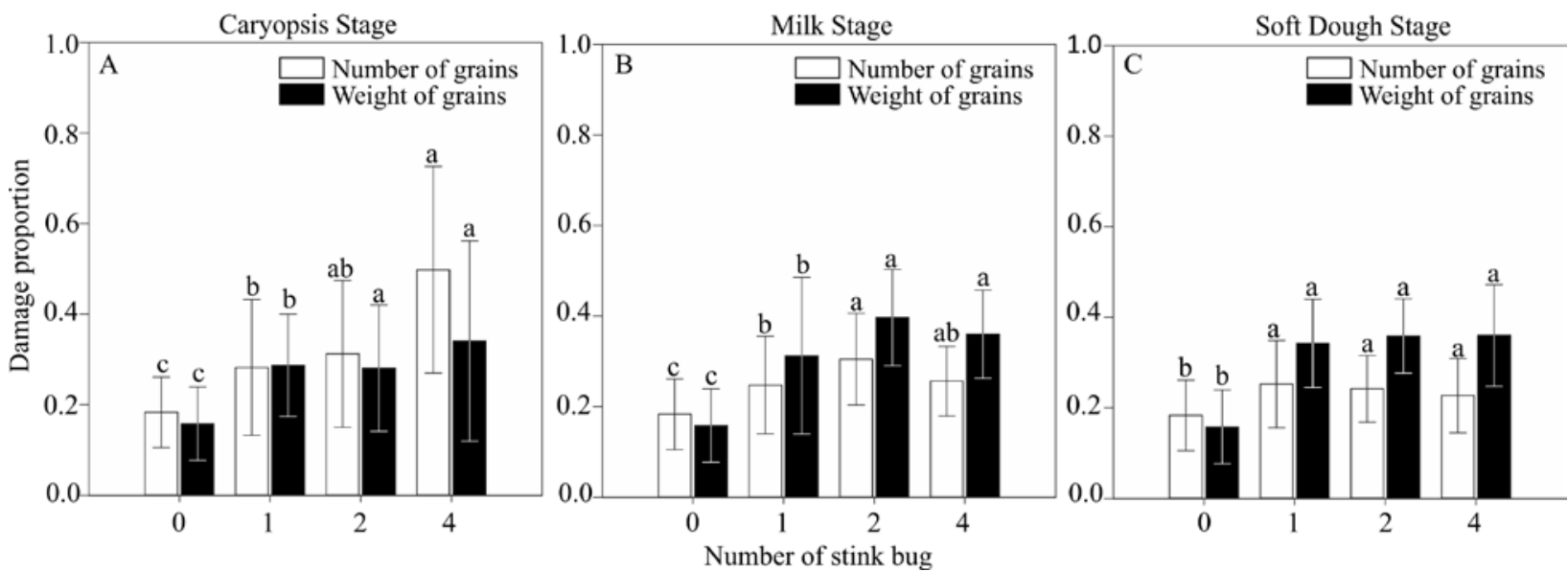

Figure 4: Proportion of damaged kernels for number and weight of grains relative to the number of Oebalus poecilus and reproductive growth stages of upland rice. 
In our study, the total number of spikelets showed no statistical difference in infestations between all reproductive growth stages, as also observed by Ferreira, Vieira and Rangel (2002), who conducted research on infestation of $O$. poecilus and $O$. ypsilongriseus in ten and five genotypes of irrigated rice, respectively. This pattern was also observed by Ferreira and Barrigossi (2006) in damage evaluating of $O$. poecilus in panicles of 39 genotypes of irrigated rice, and also in a study by Espino, Way and Olson (2007) that verified the damage caused by $O$. pugnax. This result was as expected, since the number of spikelets per panicle produced by the plant is due to genetic factors of the plant itself, and also the fact that experiments with insect infestations are usually carried out when the panicles have been liberated by the plant.

Similarly, when comparing the results of empty spikelets found in our study with other research, it can be seen that there may be a pattern in the effects caused by stink bugs feeding on rice panicles. The percentage of empty spikelets in the caryopsis stage reached $41 \%$, $42 \%$ and $83 \%$ for infestations with one, two and four $O$. poecilus adults, respectively. A similar pattern was reported by Patel, Stout and Fuxa (2006) in evaluating the damage caused by $O$. pugnax females wherein infestations made one day after anthesis/caryopsis caused infestation with one stink bug of about $40 \%$ of empty spikelets and up to $60 \%$ of damage for infestations with two insects. These authors also observed that with panicle development, the percentage decreased to less than $10 \%$ in both infestations. Other studies, also with O. pugnax, by Espino et al. (2007) and Espino and Way (2007) found a higher percentage of empty spikelets in infestations accomplished in the early stages of development of panicles.

Likewise, Silva, Ferreira and Vieira (2002) evaluated the damage caused by $O$. poecilus and $O$. ypsilongriseus in five upland rice cultivars and analysed the quantity of empty spikelets, concluding that for infestations of two stink bugs for both species, the percentage of empty spikelets exceeded $30 \%$. However, these experiments were conducted only in the milky stage panicles, thereby preventing discovery of whether this damage increased or decreased during the development of the panicles. In a similar experiment, also conducted in the milky stage and with 10 rice cultivars, Ferreira, Vieira and Rangel (2002) showed that $O$. poecilus attacks rice panicles more severely than $O$. ypsilongriseus, causing respectively $30 \%$ and $25 \%$ of empty spikelets after infestation with two stink bugs. Ferreira and Barrigossi (2006) also evaluated the damage of $O$. poecilus in 39 genotypes of irrigated rice and verified an increase in the quantity of empty spikelets in 32 genotypes after infestation with two stink bugs in the milky stage.

In studies with $O$. insularis, Rodríguez et al. (2006) supported the hypothesis that the stage most susceptible to attack from this pentatomid occurs during the first 10 days after flowering, which corresponds to the period in which the grains are being formed, and after this period, up to one insect infestation per panicle does not cause significant damage to rice grain production. However, these authors suggested that average infestations of more than 0.7 stink bugs per panicle at flowering can cause reduced grain quality and quantity, as noted by Pantoja, Daza and Duque (1993) in infestations with one, two and three couples of $O$. ornatus and $O$. insularis on 100 rice grains.

The mean number of filled spikelets (with whole grains) was inversely proportional to the number of empty spikelets and has already been affected by infestations of one stink bug in the caryopsis stage. Silva, Ferreira and Vieira (2002) did not find significant differences in the number of whole grains when evaluating the feeding of $O$. poecilus and $O$. ypsilongriseus in five upland rice cultivars, although the yield of whole grain did not exceed $46 \%$, including the control treatment, whereas in our study, the control treatment showed a percentage of whole grains larger than $80 \%$.

When the stink bug feeding occurred shortly after flowering/caryopsis it resulted in the formation of a large quantity of totally empty spikelets and a consequent reduction in the number of filled spikelets (quantitative loss). According to Barrigossi (2008), when the feeding of O. poecilus occurs in the milky stage, besides provoking a partial or total reduction in spikelet content (quantitative loss), it contributes to an increase in the incidence of peck on the grains and reduces the seed germination (quality loss). Attacks in subsequent stages result in the formation of lighter spikelets and pecky grains that often break during processing, thereby reducing the commercial value of the product (Barrigossi, 2008).

Ferreira and Barrigossi (2006), among other studies, showed that after infestation with two $O$. poecilus stink bugs early in the milky stage in 39 genotypes of rice, the mean percentage of pecky grains exceeded $75 \%$ in all plants analysed. Similar results were found by Silva, Ferreira and Vieira (2002), when they evaluated the quantity of pecky grains after infestation with both $O$. poecilus and $O$. ypsilongriseus in five upland rice cultivars. However, as these authors investigated infestations only in one panicle growth stage (milky stage), it cannot be concluded whether in the genotypes they analysed the 
percentage of pecky grains would be higher or lower, both in the earlier stages and later. However, this information does not corroborate the data observed in our results, since the mean percentage of pecky grains was significantly higher in the caryopsis stage, with $32.5 \%$ in infestations with four stink bugs, and decreased with the development of panicles. The same pattern was observed for the number of atrophied grains. The percentage of chalky grains was higher only in the soft dough stage, not exceeding $6.9 \%$.

Knowing the variety of qualitative damage caused by insects that attack the grain, as seen in our study, is important mainly because the grains with those characteristics become more susceptible to breakage during the beneficiation process, thereby reducing the percentage of whole grains. Bowling (1967) reports that panicles attacked during the milky stage generally do not present a normal grain development, producing empty spikelets or atrophied grains. Another parameter directly related to the qualitative damage is the reduction in weight of the grains (quantitative damage), which in our study reached almost $40 \%$ between treatments. The weight yield of whole grains reached $74 \%, 73 \%$ and $67 \%$ for infestation with two, one and four stink bugs, respectively, in the caryopsis, milk and soft dough stages in that order, showing that the highest mass reduction occurred in stages in which the panicles were more developed, coinciding with the stages in which the highest percentages in weights of broken grains have also been observed, reaching $20 \%$ of the total weight in the milk and soft dough stages.

Ferreira, Vieira and Rangel (2002) showed that a reduction of approximately $30 \%$ for infestation with $O$. ypsilongriseus and $38 \%$ for $O$. poecilus occurred early in the milky stage, which is a result similar to that seen in our work, which showed a decrease in grain mass of approximately $33 \%$, however for a later growth stage of the panicle. Silva, Ferreira and Vieira (2002) showed a more discreet reduction of up to $11.5 \%$ in grain mass after infestation with $O$. poecilus and $O$. ypsilongriseus performed early in the milky stage in upland rice. Patel, Stout and Fuxa (2006) obtained data similar to that of Silva, Ferreira and Vieira (2002) for the mass reduction caused by $O$. pugnax, reaching a maximum of $11 \%$ after infestation with two adult insects. These authors also report that the first 12 days after anthesis are the most critical for damage related to the reduction of grain weight.

One of the causes of the reduction of the grain weight observed in all these studies and also in our work can be explained by the papers of Swanson and Newsom
(1962) and Robinson et al. (1980), who said that when the feeding of stink bugs of panicles occurs during the milk stage it results in a greater quantity of atrophied grains and this is probably one of the factors that contributes to weight reduction during this stage. In addition, pecky grains have substantially less weight than whole grains and it is probable that the highest percentages of pecky grains observed in the different stink bug infestations have contributed significantly to the reduction of weights in the analysed stages.

However, Espino, Way and Olson (2007) found no significant difference in weight reduction in whole grains after infestation with $O$. pugnax. These authors believes that this can be explained by the compensatory responses of plants, which have a mechanism of tolerance to feeding of insects, and which in this case do not show a reduction in yield when injured, because when the stink bugs feed on developing grains, which are a "sinkhole" for the plant, they do not affect the "source" (roots and foliage), and although the feeding of insects may have caused an increase in the number of empty spikelets, plants can offset this damage by filling the grains more or increasing the movement of photosynthesis products for spikelets that were not attacked by O. pugnax (Panda; Khush, 1995).

The results presented in this study show that in upland rice (Cambará variety), the grains are susceptible to quantitative (quantity and weight of grains) and qualitative (pecky, atrophied, chalky and broken grains) damage throughout all periods of panicle development. However, when the insects feed during the caryopsis and milky stages it causes a significantly greater percentage of empty spikelets, as well as weight reduction, than when they feed on grains in subsequent stages of panicle development. Our results corroborate studies for O. ornatus (Pantoja; Garcia; Duque, 2000) and O. pugnax (Swanson; Newsom, 1962; Patel; Stout; Fuxa, 2006), which showed severe damage in rice production due to the feeding of insects during the flowering stage when compared to the next stage of panicle development. Based on these results, we believe that there are at least two explanations for increased damage to rice grains after attack by stink bugs in the early stages of panicle growth.

First, the insects are able to feed more easily on newly formed grains, since the structure of the spikelet is less resistant to puncture and insertion of the mouthparts in the seed, while in most developed spikelets the physical structure of the spikelet is more resistant/rigid. In addition, in these phases (caryopsis and milky stage), the internal contents of spikelets are still in a more liquid/pasty state 
or hardening process, and this can facilitate the feeding of stink bugs, because the insects will expend less energy on absorbing nutrients, reducing or stopping the secretion of digestive enzymes (lysosomal). This liberation of lysosomal enzymes is a food characteristic observed mainly in Hemiptera that feed on sap, such as Pentatomidae (Houseman; Morrison; Downe, 1985).

Second, the feeding of $O$. poecilus may be the same for spikelets at different ages; however, the spikelets become less susceptible to insect damage as they develop (maturing and becoming more rigid). Furthermore, spikelets in advanced stages of development and with more rigid grain require increased production and secretion of lysosomal enzymes for the digestion of proteins in liquid form, thereby increasing the energy expenditure, and therefore the stink bugs may seek less developed spikelets to feed on.

In our data, any of these explanations may be considered, especially when we look at the quantity of empty spikelets and weight reduction of filled spikelets, which were higher in infestations that occurred in the early stages of panicle development. This information can benefit producers and other researchers, allowing them to focus their monitoring of $O$. poecilus on the most susceptible stages to this pest for better informed decision-making about what control measures should be taken, and when, for the control of stink bugs of panicles. According to Weber (1989), four stink bugs per square meter are sufficient to define the level of economic damage to the rice crop; however, this author does not specify whether this value should be considered for the whole reproductive period. Barrigossi (2008) reports that the control of stink bugs of panicles must be performed when they are collected, in mean five stink bugs in ten beats of entomological net during the milk stage, and 10 insects in the next two weeks. However, these values were established considering only weight reduction damage caused during the milk stage and subsequent stages of panicle development. We therefore believe that these values must be revised, taking into account also infestations that forego the milk stage, since in our work the stage with the highest damage percentage was the caryopsis stage (R4/R5).

Due to this fact, we state that the maximum quantity of $O$. poecilus for decision-making at this stage (before the milk stage) should be 2.5 stink bugs every 10 entomological net beats (for Cambará variety). This was considered because, according to Ferreira, Vieira and Rangel (2002), controlling decisions based on the total evaluated loss should be much more rigorous than that based only on weight loss, so the number of bugs established to limit the economic injury level (n) should be reduced to approximately half $(\mathrm{n} / 2)$ because in that way other types of damage (qualitative) can also be avoided.

The establishment of population levels mentioned above was based on observations and investigations in various rice fields, and second, Bowling (1967) expects to find differences from region to region and from country to country, mainly due to factors such as climatic conditions, the infestation time of stink bugs in panicles, the relative proportion of insects per panicle, the stability of the population, the effect of parasitism eggs, the presence or absence of different types of fungi, and other factors, as the damages caused by defoliating insects (Krinski; Foerster, 2017a).

The works that have investigated the effects of feeding various species of stink bugs of panicles report that the intensity of the attack of insects is related to the stage of panicle development. Thus, losses resulting from such attacks in different genotypes and rice cultivars are probably variable. Moreover, in our study we report the damage by stink bugs of the Oebalus genus; however, several other species of stink bugs are considered pests of panicles in rice production areas worldwide, with prominence for the genera Aspavia, Cletus, Eysarcoris, Leptocorisa, Mictis, Mormidea and Nysius, among others (Ewete; Olagbaju, 1990; Pantoja et al., 1995; Ferreira; Barrigossi; Vieira, 2001; Ishizaki; Yasuda; Watanabe, 2007; Ishizaki; Tetsuya; Watanabe, 2008).

Thus, our work is the basis for the conduction of similar studies with other stink bug species that feed on rice crop, including researches with new Pentatomidae species that have recently been reported in this region on upland rice (Krinski; Foerster, 2017b; Krinski; Foerster; Grazia, 2015). Furthermore, studies should be conducted, for example, to check whether the Oebalus nymphs can cause the same damage as the adults, and also whether males and females cause similar damage, as studied in other species (Espino; Way; Olson, 2007; Espino; Way, 2007).

Besides this information, the producer must consider several other factors already reported in the studies of Barrigossi (2008), Tindall, Stout and Williams (2004) and Tindall et al. (2005) aimed at integrated pest management, in addition to the use of alternative controls such as the use of phyto-insecticides and release of natural enemies (Favetti et al., 2013; Krinski; Massaroli, 2014; Krinski; Massaroli; Machado, 2014; Piton et al., 2014; Zachrisson; Costa; Bernal, 2014; Zachrisson et al., 2014; Turchen et al., 2016ab; 2015; Krinski; Foerster, 2016; Martins; Krinski, 2016; Sanini et al., 2017). 


\section{CONCLUSIONS}

Most damage was observed in R4/R5 and R6 stages affecting the quantity (number and weight) and quality of grains (pecky, atrophy, chalky and broken grains) during all panicles development. However, the anthesis/caryopsis and milky stages are more susceptible to the $O$. poecilus attack. It is recommend that the upland rice crops should be monitored begining on panicle emission.

\section{ACKNOWLEDGMENTS}

The authors acknowledge the farmers of the Fazenda Florentino: Marlete Florentino, Eurides Florentino (in memorian) and Nadir de Lima Florentino (in memoriam) for allowing this research on their property. We also thank Leonardo Morais Turchen for help with statistical analysis, the Conselho Nacional de Desenvolvimento Científico e Tecnológico $(\mathrm{CNPq})$ and the Coordenação de Aperfeiçoamento de Pessoal de Nível Superior (CAPES) for providing scholarship to the first author (CNPq - Proc.: 141243/2012-0 and CAPES - Proc.: 939980).

\section{REFERENCES}

ALBUQUERQUE, G. S. Planting time as a tactic to manage the small rice stink bug, Oebalus poecilus (Hemiptera, Pentatomidae), in Rio Grande do Sul, Brazil. Crop Protection, 12(8):627-630, 1993.

ANTONIOLLI, Z. I.; PORTO, M. D. M. Natureza do “Pecky Rice” do arroz parboilizado no Rio Grande do Sul, Brasil. Pesquisa Agropecuária Brasileira, 26(11/12):2055-2064, 1995.

AWUNI, G. A. et al. Host preference and suitability of grasses for Oebalus pugnax. Entomologia Experimentalis et Applicata, 152(2):127-134, 2014.

AWUNI, G. A. et al. Impact of Oebalus pugnax (Hemiptera: Pentatomidae) infestation timing on rice yields and quality. Journal of Economic Entomology, 108(4):1739-1747, 2015.

BARRIGOSSI, J. A. F. Manejo do percevejo da panícula em arroz irrigado. Goiânia, Embrapa Arroz e Feijão, EMBRAPA/ CNPAF, Circular Técnica 79, 8p. 2008.

BOWLING, C. C. Insect pests of rice in the United States. In: PATHAK, M. D. The major insect pests of the rice plant. Johns Hopkins Press, Baltimore, MD., 1967. p.551-570.

CARBONELL, R. M.; SOUSA, J. G. Population dynamics of Oebalus insularis (Stål) (Hemiptera, Pentatomidae) in the rice- growing zone of Sancti Spiritus, Cuba. Centro Agricola, $7: 41-48,1980$.

CHAVES, G. S.; FERREIRA, E.; GARCIA, A. H. Influência da alimentação de Oebalus poecilus (Heteroptera: Pentatomidae) na emergência de plântulas em genótipo de arroz (Oryza sativa) irrigado. Pesquisa Agropecuária Tropical, 31(1):79-85, 2001.

CHERRY, R.; JONES. D.; DEREN, C. Establishment of a new stink bug pest, Oebalus ypsilongriseus (Hemiptera: Pentatomidae) in Florida rice. Florida Entomologist, 81(2):216-220, 1998.

CHERRY, R.; NUESSLY, G. Establishment of a new stink bug pest, Oebalus insularis (Hemiptera: Pentatomidae), in Florida rice. Florida Entomologist, 93(2):291-293, 2010.

COUNCE, P. A.; KEISLING, T. C.; MITCHELL, A. J. A uniform, objective, and adaptive system for expressing rice development. Crop Science, 40(2):436-443, 2000.

ESPINO, L.; WAY, M. O. Relative susceptibility of stages of rice panicle development to male and female Oebalus pugnax. Southwestern Entomologist, 32(4):203-211, 2007.

ESPINO, L.; WAY, M. O.; OLSON, J. K. Most susceptible stage of rice panicle development to Oebalus pugnax (Hemiptera: Pentatomidae). Journal of Economic Entomology. 100(4):1282-1290, 2007.

EWETE, F. K.; OLAGBAJU, R. A. The development of Aspavia armigera Fabricius (Hemiptera: Pentatomidae) and its status as a pest of cowpea and rice. Insect Science and Its Application, 11(2):171-177, 1990.

FAVETTI, B. M. et al. Egg parasitoids of Edessa meditabunda (Fabricius) (Pentatomidae) in lettuce crop. Revista Brasileira de Entomologia, 57(2):236-237, 2013.

FERREIRA, E.; BARRIGOSSI, J. A. F. Yield and grain quality of flood rice infested with adults of rice stink bug. Pesquisa Agropecuária Brasileira, 41(7):1083-1091, 2006

FERREIRA, E.; BARRIGOSSI, J. A. F.; VIEIRA, N. R. A. Percevejo das panículas do arroz: Fauna Heteroptera associada ao arroz. Santo Antônio de Goiás: Embrapa Arroz e Feijão. EMBRAPA/ CNPAF, Circular técnica, 43, 27p. 2001.

FERREIRA, E.; VIEIRA, N. R. A.; RANGEL, P. H. N. Evaluation of damages caused by Oebalus spp. in irrigated rice genotypes. Pesquisa Agropecuária Brasileira, 27:763-768, 2002.

FRITZ, L. L. et al. Irrigated rice agroecosystems: pest insects, natural enemies and integrated pest management. Oecologia Brasiliensis, 12(4):720-732, 2008. 
GREVE, C.; FORTES. N. D. F.; GRAZIA, J. Immatures stages of Oebalus poecilus (Heteroptera, Pentatomidae). Iheringia. Série Zoologia, 93(1):89-96, 2003.

GUHARAY, F. Biología, daño y manejo de Oebalus insularis, la chinche de la espiga del arroz. Revista Manejo Integrado de Plagas, 51:1-4, 1999.

GUTIÉRREZ, A. et al. Estimaciones de las poblaciones de Oebalus insularis en el cultivo de arroz. Ciencia y Técnica en la Agricultura, 10:43-54, 1987.

HALTEREN, P. V. Some aspects of the biology of the paddy bug, Oebalus poecilus (Dall.), in Surinam. De Surinaamse Landbouw, 2:23-33, 1972.

HOUSEMAN, J. G.; MORRISON, P. E.; DOWNE, A. E. R. Cathepsin $B$ and aminopeptidase in the posterior midgut of Phymata wolffii (Hemiptera: Phymatidae). Canadian Journal of Zoology, 63(3):1288-1291, 1985.

ISHIZAKI, M.; TETSUYA, Y.; WATANABE, T. Effect of plant species on survivorship and duration of nymphal stage in Leptocorisa chinensis (Hemiptera: Alydidae). Annals of the Entomological Society of America, 101(3):558564, 2008.

ISHIZAKI, M.; YASUDA, T.; WATANABE, T. Feeding behavior of rice bug Leptocorisa chinensis (Dallas) (Heteroptera: Alydidae) nymphs on rice panicles and rice plant extract. Applied Entomology and Zoology, 42(1):83-88, 2007.

ISHYMARU, T. et al. Formation do grain chalkiness and changes in water distribution in developing rice caryopses grown under high-temperature stress. Journal of Cereal Science, 50(2):166-174, 2009.

JONES, D. B.; CHERRY, R. H. Species composition and seasonal abundance of stink bugs (Heteroptera: Pentatomidae) in southern Florida rice. Journal of Economic Entomology, 79(5):1226-1229, 1986.

KENNARD, C. P. Effect of the paddy bug, Oebalus poecilus, on rice yield and quality in British Guyana. FAO Plant Protection Bulletin, 14(3):54-57, 1966.

KRINSKI, D.; FOERSTER, L. A. Simulated attack of defoliating insects on upland rice cultivated in new agricultural frontier from amazon rainforest region (Brazil) and its effect on grain production. Bioscience Journal, 33(1):95104, 2017a.

KRINSKI, D.; FOERSTER, L. A. Damage by Tibraca limbativentris Stål (Pentatomidae) to upland rice cultivated in amazon rainforest region (Brazil) at different growth stages. Neotropical Entomology, 46(1):107-114, 2017b.
KRINSKI, D.; FOERSTER, L. A. Toxicity of essential oils from leaves of five Piperaceae species in rice stalk stink bug eggs, Tibraca limbativentris (Hemiptera: Pentatomidae). Ciência e Agrotecnologia, 40(6):676-687, 2016.

KRINSKI, D.; FOERSTER L. A.; GRAZIA, J. Hypatropis inermis (Hemiptera, Pentatomidae): First report on rice crop. Revista Brasileira de Entomologia, 59(1):12-13, 2015.

KRINSKI, D.; MASSAROLI, A. Nymphicidal effect of vegetal extracts of Annona mucosa and Annona crassiflora (Magnoliales, Annonaceae) against rice stalk stink bug, Tibraca limbativentris (Hemiptera, Pentatomidae). Revista Brasileira de Fruticultura, 36(n.spe1):217224, 2014.

KRINSKI, D.; MASSAROLI, A.; MACHADO, M. Insecticidal potential of the Annonaceae family plants. Revista Brasileira de Fruticultura, 36(n.spe1):225-242, 2014.

MARTINS, A. L.; KRINSKI, D. First record of the parasitoid Gonatopus flavipes Olmi, 1984 (Hymenoptera, Dryinidae) in Brazil's Amazon forest. Journal of Hymenoptera Research, 50:191-196, 2016.

MCPHERSON, J. E.; MCPHERSON, R. M. Stink bugs of economic importance in America north of Mexico. CRC, Boca Raton, FL, 2000. 253p.

PANDA, N.; KHUSH, G. S. Host plant resistance to insects. CAB International, Wallingford, United Kingdom, 1995. 431p.

PANTOJA, A.; DAZA, E.; DUQUE, M. C. Efecto de Oebalus ornatus (Sailer) y Oebalus insularis Stål (Heteroptera: Pentomidae) sobre el arroz: Una comparación entre especies. Revista Manejo Integrado de Plagas, 26(1):31-33, 1993.

PANTOJA, A. et al. Relative abundance of stink bugs (Hemiptera: Pentatomidae) in south-western Colombia rice fields. Journal of Entomological Science, 30(4):463467, 1995.

PANTOJA, A. et al. Development of Oebalus ornatus (Sailor) and Oebalus insularis (Stål) (Hemiptera: Pentatomidae) on rice. Journal of Entomological Science, 34:335-338, 1999.

PANTOJA, A.; GARCIA, C.; DUQUE, M. Population dynamics and effects of Oebalus ornatus (Hemiptera: Pentatomidae) on rice yield and quality in southwestern Colombia. Journal of Economic Entomology, 93(3):276-279, 2000.

PATEL, D. T.; STOUT, M. J.; FUXA, J. R. Effects of rice panicle age on quantitative and qualitative injury by the rice stink bug (Hemiptera: Pentatomidae). Florida Entomologist, 89(3):321-327, 2006. 
PITON, L. P. et al. Natural insecticide based-leaves extract of Piper aduncum (Piperaceae) in the control of stink bug brown soybean. Ciência Rural, 44(11):1915-1920, 2014.

R CORE TEAM. 2014. R: A language and environment for statistical computing. R Foundation for Statistical. Computing, Vienna, Austria. Available in: <http://www.Rproject.org>. Access in: Sept, 10, 2016.

RAI, B. K. Laboratory and field testing of insecticides against paddy bug, Oebalus poecila (Dallas) and a technique for lowvolume drift spraying of paddy, for its control. International Rice Commission NewsI (FAO), 20:8-17, 1971.

RAI, B. K. Losses caused by the paddy bug and "red rice" in Guyana. Plant Protection Bulletin (FAO), 22:82-86, 1974.

ROBINSON, J. F. et al. Rice stink bug: Relationship between adult infestation levels and damage. Louisiana Agricultural Experiment Station Bulletin, 72:212-215, 1980.

RODRÍGUEZ, P. G. et al. Cuantificación del daño ocasionado por Oebalus insularis (Heteroptera: Pentatomidae) en el cultivo de arroz (Oryzica-1) en Panamá. Revista Colombiana de Entomología, 32(2):131-135, 2006.

SAILOR, R. The genus Solubea (Heteroptera: Pentatomidae). The Entomological Society of Washington, 46(5):105127, 1944.

SANINI, C. et al. Essential oil of spiked pepper, Piper aduncum L. (Piperaceae), for the control of caterpillar soybean looper, Chrysodeixis includens Walker (Lepidoptera: Noctuidae). Revista Brasileira de Botânica, 40(2):399-404, 2017.

SILVA, D. R.; FERREIRA, E.; VIEIRA, N. R. A. Avaliação de perdas causadas por Oebalus spp. (Hemiptera: Pentatomidae) em arroz e terras altas. Pesquisa Agropecuária Tropical, 32(1):39-45, 2002.

SWANSON, M. C.; NEWSOM, L. D. Effect of infestation by the rice stink bug, Oebalus pugnax, on yield and quality in rice. Journal of Economic Entomology, 55(6):877-879, 1962.

TINDALL, K. V.; STOUT, M. J.; WILLIAMS, B. J. Effects of the presence of barnyardgrass on rice water weevil (Coleoptera: Curculionidae) and rice stink bug (Hemiptera: Pentatomidae) populations on rice. Environmental Entomology, 33(3):720-726, 2004.

TINDALL, K. V. et al. Yield components and quality of rice in response to graminaceous weed density and rice stink bug populations. Crop Protection, 24(11):991-998, 2005.
TURCHEN, L. M. et al. Potential phytoinsecticide of Annona mucosa (Jacq) (Annonaceae) in the control of brown stink bug. Bioscience Journal, 32(3): 581-587, $2016 \mathrm{a}$.

TURCHEN, L. M. et al. Toxicity of Piper aduncum (Piperaceae) essential oil against Euschistus heros (F.) (Hemiptera: Pentatomidae) and non-effect on egg parasitoids. Neotropical Entomology, 45(5):604-611, 2016b.

TURCHEN, L. M. et al. Natural parasitism of Hexacladia smithii Ashmead (Hymenoptera: Encyrtidae) on Euschistus heros (F.) (Hemiptera: Pentatomidae): new record from Mato Grosso State, Brazil. Arquivos do Instituto Biológico, 82(1):1-3, 2015.

VIEIRA, N. R. A.; SANTOS, A. B.; SANT'ANA, E. P. A cultura do arroz no Brasil. Embrapa Arroz e Feijão. Santo Antônio de Goiás, GO. 1999, 633p.

VIVAS, C. L. E.; NOTZ, A. Plan de muestreo secuencial de Oebalus insularis Stål (Hemiptera: Pentatomidae) en el cultivo de arroz en Calabozo estado Guárico, Venezuela. Revista Científica UDO Agrícola, 9(4):857-872, 2009.

VIVAS, C. L. E.; NOTZ, A. Determination of damage threshold and level of economic vaneadora rice bug on the variety Cimarrón in Calabozo, Guarico State, Venezuela. Agronomía Tropical, 60(3):271-281, 2010.

VIVAS, C. L. E.; NOTZ, A. Spatial distribution in populations of Oebalus insularis Stål (Hemiptera: Pentatomidae) in rice in Calabozo, Guárico State, Venezuela. Revista Científica UDO Agrícola, 11(1):109-125, 2011.

WAY, M. O. Rice arthropod pests and their management in the United States. In: SMITH, C. W.; DILDAY, R. H. Rice. Origin, history, technology, and production. Wiley, Hoboken, NJ. 2003, p.437-456.

WEBER, G. Desarrollo del manejo integrado de plagas del cultivo de arroz. Cali: Centro Internacional de Agricultura Tropical (CIAT). Cali, Colombia. 69p. (Série 04.04). 1989.

ZACHRISSON, B. et al. Eggs parasitism of Tibraca limbativentris (Hemiptera: Pentatomidae), in rice (Oryza sativa) in Panamá. Revista Colombiana de Entomología, 40(2):185-186, 2014.

ZACHRISSON, B.; COSTA, V.; BERNAL, J. Incidencia natural de parasitoides de huevos de Oebalus insularis Stal (Heteroptera: Pentatomidae) en Panamá. Idesia, 32(2):119121, 2014. 